\title{
Large theropod dinosaur footprint associations in western Gondwana: Behavioural and palaeogeographic implications
}

Karen Moreno, Silvina De Valais, Nicolás Blanco, Andrew J. Tomlinson, Javier Jacay, and Jorge O. Calvo Acta Palaeontologica Polonica 57 (1), 2012: 73-83 doi: http://dx.doi.org/10.4202/app.2010.0119

In modern terrestrial ecosystems, the population size of large predators is low, and a similar pattern has usually been assumed for dinosaurs. However, fossil finds of monospecific, large theropod accumulations suggest that population dynamics were more complex. Here, we report two Early Cretaceous tracksites dominated by large theropod footprints, in Querulpa Chico (Peru) and Chacarilla (Chile). The two sites correspond to distinct depositional environments_tidal basin/delta (Querulpa Chico) and meandering river (Chacarilla) — with both subject to extensive arid or semiarid palaeoclimatic conditions. Although most trackways show no preferred orientation, a clear relationship between two trackmakers is observed in one instance. This observation, coupled with the high abundance of trackways belonging to distinct large theropods, and the exclusion of tracks of other animals, suggests some degree of grouping behaviour. The presence of freshwater sources in a dry climate and perhaps social behaviour such as pair bonding may have promoted interactions between large carnivores. Further, the occurrence of these two tracksites confirms that large theropod dinosaurs, possibly spinosaurids and/or carcharodontosaurids, existed on the western margin of Gondwana as early as the earliest Cretaceous.

Key words: Theropoda, footprints, behaviour, palaeogeography, Early Cretaceous, Gondwana, Chile, Peru.

Karen Moreno [dinohuella@yahoo.com], Laboratorio de Paleoecología, Universidad Austral de Chile, Casilla 567, Valdivia, Chile; Silvina de Valais [sdevalais@yahoo.com.ar ], CONICET - Instituto de Investigación en Paleobiología y Geología, Universidad Nacional de Río Negro, Isidro Lobo y Belgrano (8332) - General Roca, Río Negro, Argentina; Nicolás Blanco [nblanco@sernageomin.cl] and Andrew J. Tomlinson [atomlins@ sernageomin.cl], Servicio Nacional de Geología y Minería. Avenida Santa María 0104, Providencia - Santiago, Chile; Javier Jacay [jjacayh@unmsm.edu.pe], Universidad Nacional Mayor de San Marcos, EAP Ingeniería Geológica, Av. Venezuela Cd 34, s/n - Lima, Peru; Jorge O. Calvo [jorgecalvo@ proyectodino.com.ar], Centro Paleontológico Lago BarrealesUniversidad Nacional del Comahue. Calle Megaraptor 1450, Proyecto Dino, Neuquén. 
This is an open-access article distributed under the terms of the Creative Commons

Attribution License (for details please see creativecommons.org), which permits unrestricted use, distribution, and reproduction in any medium, provided the original author and source are credited.

Forill text $(760.1 \mathrm{kB})$ 